Ann. Biol. anim. Bioch. Biophys., I975, 15 (2), 419-425.

\title{
THE USE OF PROSTAGLANDINS IN CATTLE
}

\author{
J. W. LAUDERDALE \\ Agricultural Research and Development, \\ The Upjohn Company, \\ Kalamazoo, MI 49001 (U.S. A.)
}

\begin{abstract}
SUMMARY
Data support the conclusion that fertility was normal for cattle inseminated at estrus detected following $\mathrm{PGF}_{2 \alpha}$ treatment (control $=53$ p. Ioo, $\mathrm{PGF}_{2 \alpha}=52$ p. Ioo). Fertility of cows inseminated at about 72 and 90 hours after $\mathrm{PGF}_{2 \alpha}\left(56 \mathrm{p}\right.$. Ioo) suggested $\mathrm{PGF}_{2 \alpha}$ would be useful to allow breeding with normal fertility independent of estrus detection. Either two injections of $\mathrm{PGF}_{2 \alpha}$ about II days apart or administration of a progestogen for 5 to 7 days with $\mathrm{PGF}_{2 \alpha}$ administered at end of progestogen treatment were effective methods for synchronizing estrus during predefined 4 -day intervals in cattle which were having estrous cycles. Fertility was normal for inseminations made at that synchronized estrus. $\mathrm{PGF}_{2 x}$ was effective in inducing abortion during the first 120 days of gestation ( 20 of 20 aborted by day 7 after $\mathrm{PGF}_{2 \alpha}$ ), was less effective with similar doses when administered after I20 but before 250 days of gestation (24 of 53 aborted by day 35 after $\mathrm{PGF}_{2 \alpha}$ ), but was effective for inducing parturition when administered once between days 263 and 276 of gestation ( 30 cows calved an average of 3.0 days after injection).
\end{abstract}

\section{INTRODUCTION}

Four abstracts published in 1972 reported prostaglandin $\mathrm{F}_{2 \alpha}$ was luteolytic when administered to cattle by intrauterine (Rowson et al., I972 ; Lours et al., I972) or subcutaneous or intravenous (LAUDERDALE, I972) routes. During the ensuing two years, numerous publications have reported data that prostaglandins are luteolytic when administered to cattle by intrauterine, intra-muscular, or subcutaneous routes if administration was made after but not before 5 days after estrus. These data have stimulated investigations into use of prostaglandins to control sexual cycles of cattle.

To be effective for use of management of estrous cycles of cattle, prostaglandins must synchronize estrus during short, predefined intervals and fertility should be similar to normal. To be effective for use in management of pregnancy, either abor- 
tion or parturition should follow prostaglandin administration during short, predefined intervals.

Objective of this paper is to report data concerning use of prostaglandins to control estrous cycles and pregnancy in cattle. Some data reported have been published previously and will be indicated as such.

\title{
MATERIALS AND METHODS
}

\author{
Control of estrous cycles
}

Study 1.

Cows with palpable corpora lutea (CL) were assigned to one of three treatments. Cows assigned to Treatments $I$ and II were observed for estrus at least twice daily and inseminated (AI) approximately I 2 hours after the onset of estrus during either an I 8-to 25-day (Treatment I) or 7-day after $30 \mathrm{mg} \mathrm{PGF}$ P $_{2}$-Tham salt (T'reatment II) interval (table I). Treatment III cows

TABLE I

Fertility after subcuteneous or intramuscular $P G F_{2 \alpha}(\mathbf{1})$

\begin{tabular}{|c|c|c|}
\hline Treatment & $\begin{array}{l}\text { Number } \\
\text { of cattle }\end{array}$ & $\begin{array}{c}\text { Percent } \\
\text { pregnant }\left({ }^{3}\right)\end{array}$ \\
\hline Control, AI at estrus $\ldots \ldots \ldots \ldots \ldots \ldots$ & 122 & 53 \\
\hline $\begin{array}{l}\mathrm{PGF}_{2 \alpha}\left({ }^{2}\right) \text { AI at estrus within } 7 \text { days after } \\
\mathrm{PGF}_{2 \alpha} \ldots \ldots \ldots \ldots \ldots \ldots \ldots \ldots \ldots \ldots \\
\mathrm{PGF}_{2 \alpha}\left(^{2}\right), \text { AI at } 72 \text { and } 90 \text { hrs after } \mathrm{PGF}_{2 \alpha}\end{array}$ & $\begin{array}{l}69 \\
86\end{array}$ & $\begin{array}{l}52 \\
56\end{array}$ \\
\hline
\end{tabular}

(1) Lauderdale, Seguin, Stellflug, Chenallt, Thatcher, Vincent, LOYANCANO (1974).

(2) $30 \mathrm{mg} \mathrm{PGF}{ }_{2}$-Tham salt injected either subcutaneously or intramuscularly.

(3) Pregnancy based on palpation of uterus per rectum 35 to 60 days after AI.

were inseminated at approximately 72 and 90 hours after $30 \mathrm{mg} \mathrm{PGF}$. Tham salt injection without regard to the time of estrus (table I). These cows were considered to have responded to $\mathrm{PGF}_{2 \alpha}$ if during days $\mathrm{I}$ through 7 after injection either an estrus was observed or a CI, was formed as detected by rectal palpation. The uterus of each cow was palpated per rectum to determine pregnancy 35 to 60 days after AI. Fertility was calculated based on either number of cows pregnant divided by number of cows inseminated (Treatment I, II) or number of cows pregnant divided by number of cows considered to have responded to $\mathrm{PGF}_{2} \alpha$ within 7 days after injection (Treatment III). Also, fertility was calculated based on number of cows pregnant divided by the total number of cows originally assigned to each Treatment (I, II, III). For more details of experimental design, see LAUDERDALE et al., I974.

Study 2 .

Ovaries of jo beef cows, in unknown stages of the estrous cycle, were palpated per rectum for presence of a corpus luteum (CL). Similar ratios of cows with ovaries that did or did not have a CL were assigned to one of three treatment groups (table 2 ). The cows were suckling calves 
and were estimated to be at least 30 days post-partum based on palpation of uterine horn diameter. Treatment of cows assigned to the three groups (Group Number) was none (I), intramuscular injection of $3 \mathrm{mg} \mathrm{I}_{7} \varphi-\mathrm{PGF}_{2 \alpha}$ on two occasions I I days apart (II), or an intramuscular injection of $3 \mathrm{mg}$ I $7 \varphi$-PGF ${ }_{2 \alpha}$ on the last day of feeding I.o $\mathrm{mg}$ MGAR per head daily for five days (III), (table 2). All cows were managed in the same pasture, except for the five days of MGA feeding, both prior to and after start of breeding. Cows were observed for estrus twice daily and were inseminated approximately $I_{2}$ hours after last detection of " standing to be mounted ". Pregnancy was based on palpation of the uterine horns 36 to 42 and 50 to 56 days after insemination.

TABLE 2

Estrus detection and pregnancy following use of prostaglandin or prostaglandin + progestogen

\begin{tabular}{|c|c|c|c|c|c|c|}
\hline \multirow{2}{*}{ Treatment } & \multirow{2}{*}{$\mathrm{N}$} & \multicolumn{3}{|c|}{$\begin{array}{l}\text { Percent detected } \\
\text { in estrus days }\end{array}$} & \multicolumn{2}{|c|}{$\begin{array}{c}\text { Percent pregnant } \\
\text { of those }\end{array}$} \\
\hline & & $2-5$ & $1-24$ & $\begin{array}{c}\text { None } \\
1-51\end{array}$ & in estrus & total \\
\hline Control $\ldots \ldots \ldots \ldots$ & $2 y$ & — & 75 & 17 & 28 & 21 \\
\hline Prostaglandin $2 X(1) \ldots$ & 26 & $73(\mathbf{3})$ & - & 8 & 57 & 46 \\
\hline MGAR + prostaglandin ( $\left.{ }^{2}\right)$ & 20 & $75(4)$ & - & 0 & 60 & 45 \\
\hline
\end{tabular}

(1) Three (3) mg $17 \varphi-$ PGF $_{2 \alpha}$ IM two times 11 days apart.

( $\left.{ }^{2}\right)$ MGAR fed for 5 days at $1.0 \mathrm{mg}$ per head daily; $3 \mathrm{mg} 17 \varphi-\mathrm{PGF}_{2 x}$ IM day 5 of MGA.

(3) 8 i p. 100 formed new CL.

(4) $95 \mathrm{p}, 100$ formed new CL.

Control of pregnancy

Study 1 .

Thirty-two (32) pregnant cattle, based on recorded breeding dates and palpation of the uterus per rectum, were assigned randomly within stage of gestation up to I 20 days to various doses of $\mathrm{PGF}_{2 \alpha}$-Tham salt (table 3). Cattle were observed daily for signs of abortion and the ovaries and uterus palpated per rectum at least on days $\mathrm{I}, 2,3,4,5,6,7, \mathrm{I}_{4}, 2 \mathrm{I}$, and 35 after $\mathrm{PGF}_{2 x}$

TABLE 3

Effect of $P G F_{2 \alpha}$ on pregnant cattle

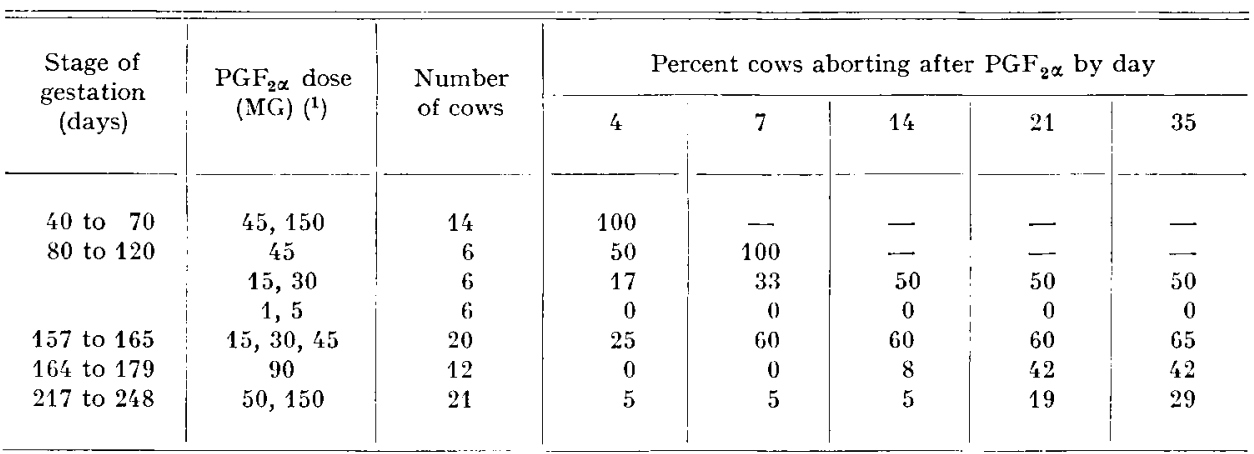

(1) $\mathrm{PGF}_{2 \alpha}$-Tham salt. Dose-Response on the same line was comparable for those doses shown. 
Study 2 .

Eighty-six (86) cattle were pasture mated and breeding dates calculated by estimating size of the amnionic vesicle by palpation of the uterus per rectum at 46 days after bulls were first introduced and at successive two- to four-week intervals. Doses of $\mathrm{PGF}_{2 \alpha}$-Tham salt were selected based on response of the previous treatment group (table 3). Doses utilized were I5, 30 , and $45 \mathrm{mg}$ ( 20 cows, I 57 to $\mathrm{I} 65$ day group), $90 \mathrm{mg}$ ( $\mathrm{I} 2$ cows, I 64 to $\mathrm{I} 79$ day group), and 50 and $150 \mathrm{mg}$ (2I cows, 217 to 248 day group) (table 3 ). Cows and pens were observed at least once daily for signs of abortion. The uterus of each cow was palpated per rectum to detect presence of a fetus at various time intervals following $\mathrm{PGF}_{2 \alpha}$.

Thirty-three (33) cows were assigned randomly to be injected with various doses of $\mathrm{PGF}_{2^{\alpha}}$ Tham salt in an attempt to induce parturition at about day 267 of gestation (table 4 ).

TABLE 4

Effect of $P G F_{2 \alpha}$ induction of parturition in cattle

\begin{tabular}{|c|c|c|c|c|c|c|c|}
\hline \multirow{3}{*}{$\begin{array}{l}\mathrm{PGF}_{2 \alpha} \text { dose } \\
(\mathrm{MG})\left({ }^{1}\right)\end{array}$} & \multirow{3}{*}{$\begin{array}{l}\text { Number of } \\
\text { cows }\end{array}$} & \multicolumn{4}{|c|}{ Day of gestation } & \multirow{2}{*}{\multicolumn{2}{|c|}{$\begin{array}{l}\mathrm{PGF}_{2 \alpha} \text { to calving } \\
\text { interval (days) }\end{array}$}} \\
\hline & & \multicolumn{2}{|c|}{ Injected } & \multicolumn{2}{|c|}{ Calved } & & \\
\hline & & Mean & Range & Mean & Range & Mean & Range \\
\hline $15,30,45,90$ & 30 & 267.9 & $263-276$ & 271.0 & $266-277$ & 3.0 & $1-8$ \\
\hline 5 & 3 & 263.3 & $260-267$ & 278.3 & $269-287$ & 15.0 & $2-24$ \\
\hline
\end{tabular}

(1) Single administration of $\mathrm{PGF}_{2} \alpha$-tham salt subcutaneously. Dose-response on the same line was comparable for the doses shown.

\section{RESULTS}

Study 1.

\section{Control of estrous cycles}

Percent animals pregnant at 35 to 60 days after $A I$ was 53,52 , and 56 for Treatments I, II, and III, respectively (table I). Differences in fertility among the three treatments did not approach statistical significance $(P>0.05)$.

Percent of the cows pregnant by end of the breeding season is of paramount interest to the producer. Although this study was not designed to evaluate management programs using $\mathrm{PGF}_{2} \alpha$, the percent of each experimental group pregnant was calculated. Percent of the total number of animals assigned to Treatments I, II, and III that were pregnant following one breeding during 18 to 25 days for Treatment I, 7 days for Treatment II, or only at 72 and 90 hours after $\mathrm{PGF}_{2 \alpha}$ for Treatment III was $42,3^{\circ}$, and 40 , respectively. These values reflect degree of estrus detection (Treatments I, II), precision of response to prostaglandin ('Treatments II, III), and conception rates; (Treatments I, II, III).

About 50 percent of the cattle were detected in estrus on day 3 after $\mathrm{PGF}_{2 \alpha}$ 
injection, but 88 percent were detected on days 2, 3, and 4 after injection (LAUDERDALE et al., I974). Spread in interval between injection and detection of estrus was greater than that reported previously (LoUIs et al., I973 ; LAUDERDALE, I972 ; INSKEEP, I973), possibly because previous studies utilized cattle at known stages of the estrous cycle.

\section{Study 2.}

Percent cows detected in estrus and duration of estrus detection was 75 and 22 days, 73 and 4 days, and 75 and 4 days for Treatments I, II, and III, respectively (table 2). In addition, 3 and 4 cows of Treatment II and III that were not detected in estrus during the synchronized interval were detected about one normal estrous cycle interval after the synchronized interval, suggesting that $\mathrm{CL}$ were formed but the cows were not detected in estrus. Percent cows that were not detected in estrus during the first 5 I days of breeding were $I 7,8$, and 0 for Treatments I, II and III, respectively (table 2 ).

Percent cows pregnant was 28,57 , and 60 following insemination at one estrus detected during 22 days (I), 4 days (II), or 4 days (III), respectively (table 2 ). No basis has been detected for the "low "pregnancy rate for controls; $i$. e., basis for assignment was similar for the three treatments, cows were managed in the same pasture, different inseminator frequency was similar between the three treatments. Based on total number of cattle assigned to each treatment, percent cattle pregnant after either 22 or 4 days of breeding was 2 I, 46 , and 45 for Treatments I, II, and III, respectively (table 2). These latter pregnancy rates reflect degree of estrus detection as well as establishment of pregnancy following insemination.

\section{Control of pregnancy}

\section{Studies 1 and 2.}

Doses of $45 \mathrm{mg}$ or greater of $\mathrm{PGF}_{2 \alpha}$-Tham salt resulted in abortion of 20 of 20 cows by day 7 after $\mathrm{PGF}_{2 \alpha}$ injection if administered prior to day $\mathrm{I} 20$ of gestatic $n$ (table 3). Doses of $30 \mathrm{mg} \mathrm{PGF}_{2}{ }$-Tham salt or less were less effective or ineffective in inducing abortion during this same interval (table 3 ). Doses as high as $\mathbf{r}_{5} \mathrm{O} \mathrm{mg}$ $\mathrm{PGF}_{2} \alpha$-Tham salt were less effective for inducing abortion when administered between days I57 $_{5}$ and 248 of gestation (table 3 ). Parturition was induced an average of 3 days after $\mathrm{PGF}_{2 \alpha}$ injection (table 4). Some of the above cited data have been published (LAUDERDALE, I972 ; LAUDERDALE, et al., I974). Two of 30 calves died during or following parturition, a loss rate consistent with the normal loss rate in this herd. All cows had retained fetal membranes for greater than 2 days but less than 7 days. Fetal membranes were not removed nor were cows treated with antibiotics. Corpora lutea (CL) had regressed to I 2 to $\mathrm{I} 4 \mathrm{~mm}$ by three days after $\mathrm{PGF}_{2 \alpha}$ injection in all cows that aborted when treated during the first r2o days of gestation. For those cows whose ovaries could be palpated between $\mathrm{I}_{57}$ and 248 days of gestation, CL, regressed in those cows that aborted. CL, did not regress in cows whose ovaries could be palpated but did not abort. 


\section{DISCUSSION AND CONCLUSIONS}

\section{Control of estrous cycles}

Fertility was normal when cattle were inseminated at synchronized estrus following $\mathrm{PGF}_{2 x}$ and fertility was normal when cattle were inseminated at predefined intervals following $\mathrm{PGF}_{2} \alpha$. The similarity of fertility between controls and cows inseminated by appointment at approximately 72 and 90 hours after $\mathrm{PGF}_{2}$ injection suggests $\mathrm{PGF}_{2 \alpha}$ may be useful to allow breeding with normal fertility at predefined times, independent of estrus detection. Data previously summarized support the conclusion that fertility was normal for cattle inseminated at estrus detected following $\mathrm{PGF}_{2 \alpha}$ treatment, $\mathrm{C}=59 \mathrm{p} . \quad$ IOO, $\mathrm{PGF}_{2 \alpha}=59$ p. IOO (LAUDERDALE, I973).

Prostaglandins do not regress the $\mathrm{CL}_{1}$ consistently when administered prior to day 5 of the estrous cycle, therefore, in order to synchronize estrus in groups of cattle, some type of prostaglandin administration must be employed other than single administration. Two injections of $\mathrm{PGF}_{2 \alpha}$ at II days apart demonstrated this method to be effective for synchronizing estrus with no reduction in fertility. GRAves et al., (I974) also reported two injections of $\mathrm{PGF}_{2} \alpha$ Io days apart was effective for synchronization of estrus in cattle. HEERSCHE et al., (I974) reported that adninistration of a progestogen by implant for seven days with $\mathrm{PGF}_{2}$ injected on day 7 resulted in a high degree of estrus synchronization and normal fertility. Feeding of $\mathrm{MGA}^{\mathrm{R}}$ for five days with prostaglandins injected on day 5 also resulted in a high degree of estrus synchronization and apparent normal fertility.

Information cited above demonstrated that either two injections of prostaglandins about I I days apart or 5 to 7 days of progestogen administration in conjunction with prostaglandin on or about the last day of progestogein administration are two effective methods for synchronizing estrus during a predefined interval of 4 days in cattle which are having estrous cycles. Fertility has been normal for insemiations made at this synchronized estrus.

\section{Control of pregnancy}

Pregnant heifers appeared to be more responsive to $\mathrm{PGF}_{\mathbf{2}} \alpha$-Tham when administered prior to 120 and after 260 days of gestation. This statement is based on Ioo percent success rate with doses of $45 \mathrm{mg}$ (up to r2o days) or $\mathrm{I}_{5} \mathrm{mg}$ or greater (26o days or greater) compared to less than 66 percent success rate with doses of greater than $45 \mathrm{mg}$ (days I5O to 250). Progesterone has been reported to be necessary to maintain pregnancy in the cow through at least days I80 to 200 of gestation but may or may not be necessary after day 200 (TANABE, I970). CL regression to a " hard " structure of I2 to I4 mm size (based on palpation per rectum) within 2 to 3 days but abortion occurring 2 to $\mathrm{I}_{4}$ days after $\mathrm{PGF}_{2 \alpha}$-Tham injection suggested $\mathrm{PGF}_{2}{ }^{\alpha}$-Tham caused $\mathrm{CL}$ regression which was followed by abortion. If these cause and effect relationships are correct, the reduced response obtained between days I 50 and 250 would be expected. However, data to date do not allow for interpretation of specific cause and effect relationship between effect of $\mathrm{PGF}_{\mathbf{2} \alpha}$-Tham, CL, regression, and abortion. 
Parturition was induced an average of 3 days after $\mathrm{PGF}_{2 x}$ but the range was $\mathrm{I}$ to 8 days. A subsequent report by SPEARs et al., I974 demonstrated parturition was induced an average of 43 hours after $\mathrm{PGF}_{2 \alpha}$. These data suggest $\mathrm{PGF}_{2} \alpha$ to be effective for inducing parturition in cattle.

Colloque: Control of sexual cycles in domestic animals October 27-30, 1974, Nouzilly.

\section{RÉSUMÉ}

\section{UTILISATION DES PROSTAGLANDINES CHEZ LES BOVINS}

Certaines données viennent confirmer la conclusion que la fertilité des vaches qui ont subi l'insémination artificielle au moment de l'œstrus après un traitement $\mathrm{PGF}_{2 \alpha}$ (témoins $-53 \mathrm{p}$. ıoo, $\mathrm{PGF}_{2 \alpha}-5^{2} \mathrm{p}$. 100 ) est normale. La fertilité des vaches qui ont été inséminées dans un délai de 72 à 90 heures après administration de $\mathrm{PGF}_{2 \alpha}\left(56 \mathrm{p}\right.$. 10o) permet de croire que la $\mathrm{PGF}_{2 \alpha}$ pourrait se révéler utile pour permettre la reproduction chez des animaux de fertilité normale, indépendamment de la détection de l'ostrus. On a constaté qu'une des méthodes suivantes, soit deux injections de $\mathrm{PGF}_{2 \alpha}$ à environ I I jours d'intervalle, soit l'administration d'un progestagène pendant 5 à 7 jours avec injection de $\mathrm{PGF}_{2 \alpha}$ à la fin du traitement avec progestagène, sont aussi efficaces pour synchroniser l'œstrus durant des intervalles de 4 jours prédéfinis chez des vaches avec des cycles œstriens normaux. La fertilité a été normale pour les inséminations pratiquées au moment de cet œestrus synchronisé. La $\mathrm{PGF}_{2 \alpha}$ a été intégralement efficace pour déclencher l'avortement durant les I 20 premiers jours de la gestation (20 vaches sur 20 ont avorté au jour 7 suivant l'administration de $\mathrm{PGF}_{2} \alpha$ ) mais a été moins efficace, à des doses similaires, quand on l'a administrée entre 120 et 250 jours de gestation (24 vaches sur 53 ont avorté au jour 35 suivant la $\mathrm{PGF}_{2 x}$ ). La prostaglandine $\mathrm{PGF}_{2 \alpha}$ a été également efficace pour déclencher la misebas quand on l'a administrée une seule fois entre les jours 263 et 276 de la gestation (30 vaches ont mis bas en moyenne 3,0 jours après l'injection).

\section{REFERENCES}

Graves N. W., Short R. E., Randel R. D., Bellows R. A., Kaltenbach C. C., Dunn T. G. 1974. Estrus and pregnancy following MAP, $\mathrm{PGF}_{2 x}$ and GnRH. J. Anim., Sci., 39, 208-209.

Heersche G., Kiracofe G. H., McKee R. M., Davis D. L., Brower G. R., I974. Control of estrus in heifers with $\mathrm{PGF}_{2 x}$ and Synchro-Mate B. J. Anim. Sci., 38, 225 (abstract).

Inskeep E. K., 1973. Potential uses of prostaglandins in control of reproductive cycles of domestic animals. J.Anim. Sci, 36, II $49^{-1}$ I 57 .

Lauderdale J. W., I972. Effects of $\mathrm{PGF}_{2 x}$ on pregnancy and estrous cycles of cattle. J. Anim. Sci., 35, 246 (abstract).

LAUderdale J. W., I973. Fertility and sperm transport following prostaglandin or progestogen treatment of cattle. In : Transport, survie et pouvoir fécondant des spermatozoüdes chez les vertébrés. I. N. S. E. R. M., 26, 499-512.

Lauderdale J. W., Seguin B. E., Stellflug J. N., Chenault J. R., Thatcher W. W., Vincent C. K., Loyancano A. F., I974. Fertility of cattle following PGF ' $_{2}$ injection. J. Anim. Sci., 38, 964-967.

Louis T. M., Hafs H. D., Morrow D. A., I972. Estrus and ovulation after uterine PGF $2 \alpha$ in cows. J. Anim. Sci., 35, 247-248.

Louis T. M., Hafs H. D., Seguin B. E., I973. Progesterone, LH, estrus, and ovulation after prostaglandin $\mathrm{F}_{2 \alpha}$ in heifers. Proc. Soc. Exp. Biol. Med., 143, 152-155.

Rowson L. E. A., Tervit R., Brand A., 1972. The use of prostaglandin for synchronization of oestrus in cattle. J. Reprod. Fertil., 29, I 45 (abstract).

Spears L. L., Bercovitz A. B., Reynolds W. L., Krieder J. L., Godke R. A., I974. Induction of parturition in beef cattle with estradiol and $\mathrm{PGF}_{2 x}$. J. Anim. Sci., 39, 227 (abstract).

TANABE T. Y., I970. The role of progesterone during pregnancy in dairy cows. Pennsylvania State Univ. Coll. of Agri. Bull., ry4. 